\title{
Dative Case Verbs in Japanese
}

\author{
Made Ratna Dian Aryani \\ Faculty of Arts, Udayana University \\ dian_aryani@unud.ac.id
}

\begin{abstract}
This study aimed to describe the dative case verbs in Japanese syntactically and semantically. Specifically, it aimed to explore the verbs that take an indirect object (IO) in the Japanese sentences. The theories used in this research were the theory of Givon (2001), and Nitta (1991). The data used in this research were the data obtained from Japanese corpus. The research method used was descriptive analysis. This research indicated that dative case verbs are verbs whose presence would potentially take an IO. The results of this research were (1) The verbs that require the presence of an IO in Japanese is a transitive verb, with the marker ni, and (2) those verbs are ageru 'give', oshieru 'teach', kureru 'give' and kau 'buy'. Semantically these verbs are keizoku doushi 'continuative verbs'.
\end{abstract}

Keywords: dative, double object, indirect object

\section{INTRODUCTION}

Linearity is an aspect and also the characteristics of a language. There are two things associated with linearity, namely (1) the existence of lingual units as articulated language elements, (2) the order of the units as a means of forming grammatical constructions (Sudaryanto, 1983: 1). The units are sorted in the sequencing process and form an arrangement. Typologically, the languages of the world show that the sequence patterns in each language have a style in its subordinates concerning internal construction is in it. Lehmann (in Sudaryanto, 1983: 6) states that "each central of a language is the verb". That is, it is the verb to first determine the structure of the various constructions in the language in question and their changes. The main function of a verb is as a predicate or as the core predicate in a sentence.

Chafe (1970: 98-100) classifies verbs into four, namely the situation, process, action, and action-process. Furthermore, Chafe stated that the verb is the core proposition that elicits a noun or noun phrase that must be present together with the verb. Verbs also determine the role of semantic noun/noun phrases and semantic features of nouns that must be present to accompany the verb in building a proposition. Furthermore, Chafe explained that the semantic structure is based on a series of relationships between the core and the verbs as nouns which have bound specifically to the verbs semantic relationships that bind. Semantic structure can be seen through the case in the framework of the Grammar case, while the case is the role of semantic argument verbs. The new semantic structure of verbs can be formulated if understood semantic roles. In analyzing the role of semantic note is characteristic of the verb and semantic relationships between verbs as predicates and arguments are bound by the verb.

Valence difference yields the relationship that varies between verbs and arguments. By category, verbs can be classified into three, namely (1) the verb with one argument, (2) the verb with two arguments, and (3) the verb with three arguments.

\section{Japanese (BJ)}

The verb with one argument

$\begin{array}{ll}\text { (1) 雨が } & \text { 降っています。 } \\ \text { Ame ga } & \text { futte imasu. } \\ \text { rain-Nom } & \text { fall-Morf (PROG) } \\ \text { Subject } & \text { Verb } \\ \text { 'Rain is falling.' } & \end{array}$

\section{The Verb with two arguments}

$\begin{array}{lll}\text { (2) 私は } & \text { 魚を } & \text { 食べます。 } \\ \text { Watashi } & \text { sakana o } & \text { tabemasu. } \\ \text { wa } & \text { fish-Ac } & \begin{array}{l}\text { eat-Morf } \\ \text { (FUT) }\end{array} \\ & \text { Object } & \text { Verb }\end{array}$

'I would eat fish.' 
The Verb with three arguments

(3)

タロは
Taro
Taro-Top
Subject

花子に

Hanako ni

Hanako-Dat

Indirect Object
車を

kuruma o

car-Ac

Object
買います。

kaimasu.

buy-Morf

Verb

'Taro bought a car for Hanako.'

Based on the sentence example above, sentence (1) the verb futte imasu 'fall (for rain)' is an intransitive verb with ame ga 'rain' functioning as the subject, and demonstrate the verb with one argument, sentence (2) the verb tabemasu 'will eat ' is a transitive verb with watashi wa 'I' functioning as the subject and sakana $o$ ' fish ' as the object, and shows the verb with two arguments, and example sentence (3) the verb kaimasu' buy 'is a transitive verb with Ari san wa 'Ari ' functioning as the subject, Dian san $n i$ 'Dian' as the indirect object, and kuruma $o$ 'car' as a functioning as the direct object, and shows threeargument verb that demands the presence of the dative case ' $\boldsymbol{n i}$ ' (IO).

Based on the above phenomenon, which will be the focus of this research and the need to study the semantic structure of Japanese verbs, so it will obtain a clear picture that is a verb which has three arguments in Japanese and marked with the dative case ' $\boldsymbol{n i}$ ' in an IO.

\subsection{The Concept of Verb}

Verhaar (1999) claimed that the verb in sentence construction is the constituent head. As a constituent head, the verb has the task of giving birth to the other constituents. The constituent of the sentence is referred to as a noun. The properties (roles) of nouns also depend on the nature of the verb as a head. When presence a dative constituent is not obligatory, it will be assumed that the verb is not a verb that requires the presence of an IO and certainly dative case will not appear.

According to Givon (2001: 64-73) characteristics of a verb can be observed through three characteristics, namely semantic, morphological, and syntactic characteristics. Semantic features of verbs tend to refer to the circumstances, processes and actions. Morphological traits showed that the verb is marked by the addition of affixes which in certain states modality, aspect, tense, negation, pronominal adjustment, and case markers. Meanwhile, the syntactic characteristics reveal that a verb, in general, is the sentence which in this study would still be called the verb phrase. At the morphological level, observation in Japanese is inseparable from the philosophy of grammar, namely the function, form, and meaning. This means that this study, in addition to observing the functions and forms of the verb, it also observes meaning because

\section{(JL. 1996:265)}

verbs produce different types of verbs that certainly influence the verb valence.

The comprehension of Japanese sentences based on case particles. To analyze the data obtained, the terms proposed by Tsunoda (2002: 66) will be used as follows:

Terms 1: Roles are generally bound only with case particles: $\boldsymbol{g a} \boldsymbol{n} \boldsymbol{n i}$, and $\boldsymbol{o}$

Terms 2: In each sentence, particle $g a$ is attached to one of the arguments no more than one.

Term 3: In each sentence, sometimes arguments are not attached with case particle $\boldsymbol{o}$, and when the particles that case arises, no more than one.

Term 4: In each sentence, if the argument is not attached to particle $\boldsymbol{g} \boldsymbol{a}$ and $\boldsymbol{o}$, it will appear with particle $\boldsymbol{n i}$.

However, from a combination of particles of this case, it does not mean that every verb is acceptable for the meaning of the verb also determines the meaning relationship that exists between the verb and its arguments.

\subsection{Theoretical Framework}

Dative generally functions as an IO of the verb. In Japanese, it typically uses particle ni. Tsujimura (1996: 165) states that in any constituent of Japanese, there is a marker to explain its function, namely markers nominative subjects (topics) that ga and the topic is wa, markers accusative object is $\boldsymbol{o} /$ $\boldsymbol{w o}$, markers dative is ni, markers genitive ownership is no, markers are complementary to. The marker is placed after the word and shows grammatical relationships in the sentence. Tsujimura (1996: 134) states:

"Case particles include Nominative (Nom) $\sim$ ga, Accusative (Acc) o, Dative (Dat) ni, and Genitive (Gen) no, and these we add the Topic (Top) marker $\sim$ wa. The Dative Case $\sim$ ni is primarily associated with verbs of giving, and together with the noun, it implies the recipient."

The function of particles in the case of BJ sentences would be to give the semantic

role of the noun. Nitta (1991: 66) explains the marker case or kakujoshi 格助詞：が、の、を、に、で、 へ、と、から、より、まで、これは、先行する 名詞あるいは代名詞の格示します。”Kakujoshi: ga, no, o, ni, de, e, to, kara, yori, made, senkou suru 
kore wa wa meishi arui daimeishi no kakushimeshimasu". "That includes kakujoshi is ga, no, o, ni, de, he, kara, yori, made. The presence of all joshi in a sentence preceded by a noun or pronoun. ' In connection with this, consideration of the experts, for example, the theory of theta (Theta theory) in transformational grammar developed by Nagashima (1983), Radford (1988), Comper (1992), and Tsujimura (1996), shows the study of syntax to the end this century cannot ignore the case (role) in terms of semantic relationships. Nitta (1991: 135) argues that the use of the particle "ni" is as follows:

(A) 在り場所を表す, "Aribashou o arawasu" Declare the existence somewhere. Example: 庭に池がある.niwa ike ni ga aru. "In the yard, there is a pool".

(B) 行〈先老表与. "Yukusaki o arawasu" Stating a goal. Example sentence: 大阪に 行 く. Oosaka ni iku. "Go to Osaka",

(C) 物の授受行う相手を表す."Mono no juju okonau aite o arawasu 'Stating the recipient/giver of goods. Example: 彼にぺ ンを上げる.kare ni o ageru pen. "Give him a pen.

(D) 動作や態度が向けられる先を表. "Sin yes taido mukerareru saki ga o arawasu" Declare target object of an action director. Example: "母に甘える.Haha ni amaeru. "Pampered mother",

(E) 原因を表守. "Gen'in o arawasu" Declare cause, origin, for example: がんに死 ぬ.Gan ni Shinu. "Died of cancer".

$(F)$ 変化の先老表与. "Henka no saki o arawasu" Declare the result of variations/changes, for example: 水が氷に なる Koori Mizu ni ga naru. "Water becomes ice".

(G) 形容詞の表す状態がなり立つの基準や志 し向対象こうたいしょうなどを表す。 "Keiyōshi no arawasu jōtai ga nari tatsu no Kijun Yes kokorozashi Ko Ko Taishou Taishō nado o arawasu" Declare a state consisting of a target object, standard, range. example: 彼は日本史に明るい. "Kare wa ni nihonshi Akarui. "He's a lot to know the history of Japan".

(H) 動作の目的表表守."Dousa no mokuteki o arawasu" Stating the purpose of an activity. For example: 花見に行く. Hanami ni iku. "Went to see the cherry blossoms."

(I) 時を表す. "Toki o arawasu" Declare a time, for example: 七時におきる. 7ji ni Okiru. "Woke up at 7 o'clock".

(J)動詞を受身文にしたときの動詞の 主体を表す. "Doshi o ukemibun ni shita toki no Doshi no, Shutai o arawasu" Declare the subject of the passive sentence Example:
子供に死なれた. Kodomo ni shinareta. "Left to die by children".,

(K) 動詞を使役文にしたときの, 動詞の 主体を表す. "Doshi ni shita o shiekibun toki no, Doshi no Shutai o arawasu" Declare causative subject of the sentence. Example: 彼にその仕事をやらせた."Karenio sono shigoto yaraseta. "Make him do the job.

In this study, such as the marker function ni described by Nitta, then the points (C) who will be the focus. At the point (C) explains a significant marker $n i$ dative/receiver that marked the presence of an IO.

\section{RESEARCH METHODS}

The data in this study are in the form of a modern Japanese transitive verb construction with dative cases used today, which is compiled from a Japanese corpus of data. This is done with the consideration that the source of the data is used to represent Japanese common usage and is comprehensive. Japanese dative case study is a form of qualitative descriptive, explanatory, and synchronous for data described in this research done by giving an overview and explanation of the circumstances or the reality of the language as it is.

The analysis is based on (1) constituents marked by particle $\boldsymbol{n i}$, (2) the syntactic elements are associated with the presence of verbs in the construction of the dative case, (3) the types of nouns that are present in the an $\mathrm{IO}$ constituent of dative case constructions and (4) the semantic roles of constituents building construction Japanese dative case constructions. The results of the analysis of this data can be used as a basis for making rules of any construction. The method used in this research is the distributional method with the basic technique is immediate constituent analysis.

\section{RESULTS AND DISCUSSION}

This section will discuss the determination of Japanese dative case verbs and discussion about the semantic structure of Japanese dative verbs.

The conception of cases is associated with the marking system in Japanese. Japanese sentence structure containing particles は ' $w a$ ', が ' $g a$ ', に 'ni' へ 'he', を'o/wo', で 'de' that show grammatical relationships in the sentence. Japanese particles serve to explain the relationship between words in a sentence. The basic principles of particle or in the teaching of Indonesian are known as a preposition. A preposition refers to the presence of particles preceding a noun, whereas in Japanese these particles appear after a noun which is often called postposition.

Case in Japanese is usually given to a noun which is one of the features that determine the grammatical form of the noun; in a systematic 
indicator, it shows the semantic-syntactic relation with sentences that contain nouns. It can be said, the case is a typical feature, by changing the form of the noun, syntactic relationships such as subject, object, semantic relationships, such as places, and objects to be subjected to the action is a sentence that contains nouns that are indicated by a marker. Central in the structure of the sentence is the predicate. This predicate slot is filled by a verb. Tsunoda (2002) pointed out that ditransitive verbs require the presence of the subject function, object functions, complementary functions, and predicate functions that form the structure of $\boldsymbol{S}-\boldsymbol{O}-\boldsymbol{C}-\boldsymbol{P}$.

Kuno (1973: 165) states 与格は一般に動詞 の間接目的を表示する。日本語では主に「に」 で表される。'Yokaku ippan wa ni Doushi no kansetsumokuteki o hyouji suru. Nihongo de wa Shuni (ni) de arawasareru.' A dative is generally an indirect object (IO) of the verb. In Japanese, it typically uses particle $n \boldsymbol{n}$.

\section{Hanako が Tarooに英語を \\ Hanako ga Taroo ni eigo o \\ Hanako-Nom Taroo-Dat \\ 教えます。 \\ Agen \\ OTL \\ oshiemasu. \\ English-Ac \\ Obyek \\ teach \\ Verba}

'Hanako teaches English to Taroo'.

$\begin{array}{ll}\text { 5. Jiroo が } & \text { Masako に } \\ \text { Jiroo ga } & \text { Masako ni } \\ \text { Jiroo-Nom } & \text { Masako-Dat } \\ \text { Agen } & \text { OTL }\end{array}$

'Jiroo give the ring to Masako.'

\author{
指輪をあげた。 \\ yubiwa o age-ta. \\ ring-Ac give-PERF \\ Obyek
} Verba

(Corpus, Gengogaku: 1996)

On the data line (4) and (5), arguments that appear are the arguments Hanako ga and Jiroo ga an agent, Taroo $n i$ and Masako $n i$ is the (IO) as dative/receiver, and eigo o and yubiwa $o$ is the object direct (DO/object). In Japanese, the role of agents, experiencer, receiver, objects, and the other is a case marked, each marked with the particle $\boldsymbol{g a}, \boldsymbol{o}$, and $\boldsymbol{n i}$.

6. 彼が

kare ga

(male).3SG-Nom

Subject

私に

watashi ni

花を

1SG-Dat

hana $o$

Indirect Object Object

くれました。

kuremashita.

give- morf-PAST (polite).

Verb

'He gave me flowers.'

7. 田中先生は

Tanaka sensei wa

Teacher Tanaka-Top

Subject

教えて下さいます。

oshitekudasaimasu.

teach-morf- PROG (polite).

Verb
Particle ga (agent), $\boldsymbol{o}$ (experiencer), and wa (agent / topic), ni (receiver). Particles used as markers required to meet the case and grammatical functions. Thus, one can say that the particle is a grammatical semantic role. Particles serve to explain the relationship between words in a sentence.

$\begin{array}{ll}\text { 私たちに } & \text { 日本語を } \\ \text { watashitachi } \boldsymbol{n i} & \text { nihongo o } \\ \text { 1PL-Dat } & \text { Japanese-Ac } \\ \text { OTL } & \text { Object }\end{array}$


'Mr. Tanaka was teaching Japanese to us.'

(Korpus, Yahoo Japan! 2006)

In sentence (6), kare ga argument is a doer (agent), watashi $n i$ is the goal/objective (IO), and hana $o$ is a theme (theme). The verb in sentence (6) is an action verb is kuremashita that is syntactically a verb that requires the presence of indirect object (IO) argument.
Likewise in the example sentence (7), Tanaka-sensei $w a$ is the doer (agent), watashitachi $n i$ are the goals/targets, and verb oshite kudasaimasu is an action verb that requires the presence of indirect object (IO) argument.

\section{8. タロの 奥さんが タロに 着物を \\ Tarono okusanga Taroni kimonoo \\ Taro-Gen wife-Nom Taro-Dat kimono (Japanese clothes)-Ac \\ Subject OTL Object \\ 買ってしまった。 \\ katteshimatta. \\ give-morf-cont-intentional-PAST. \\ Verba \\ 'Taro's wife intentionally bought a kimono for Taro.'}

(Korpus, Gengo:2003)

Sentence (8), the argument Taro $g a$ is no okusan actors (agents), Taro $n i$ is the recipient (IO), kimono $o$ is the theme (object), and katte shimatta is an action verb. In sentence (8) the argument (IO) with the particle $n \boldsymbol{n}$ (dative) shows as a recipient/benefactive.

9. a. Kato さんは Ø車を 買いました。

Kato san wa $\varnothing \quad$ kuruma o kaimashita.

Kato-Top $\varnothing \quad$ car-Ac buys (PAST).

'Kato has bought a car.'

b. Katoさんは Satoさんに 車を 買ってあげました。

Kato san wa Sato san ni kuruma o katteagemashita.

Kato-Top Sato-Dat car-Ac buy (PAST).

'Kato bought a car for Sato'

(Korpus, Gakubu:2005)

10. a.* 母は $\varnothing$ お金を 上げた。

Hahawa $\varnothing$ okaneo ageta.

mother-Top $\varnothing$ money-Ac give(PAST).

'Mother was giving some money.'
b. 母は妹にお金を上げた。

$\begin{array}{llll}\text { Haha wa } & \text { imouto } n i & \text { okane o ageta. } \\ \text { mother-Top } & \text { sibling (female)-Dat } & \begin{array}{l}\text { money-Ac } \\ \text { give }\end{array}\end{array}$

'Mother gave some money to sister.'

(Furanki,2005: 324)

Analysis of sentence (9) indicates that with the use of verbs kaimashita with deletion indirect object (IO) argument in sentence (9a), and without deletion indirect object (IO) arguments in sentence (9b) can remain independent and grammatically acceptable in Japanese and Indonesian. Kato san wa argument is the doer (agent), kuruma $o$ is the theme (object), and kaimashita are action verbs/action on the data (9a). Data (9a) does not raise the argument (IO). While the data (9b) Kato san wa argument is the doer (agent), Sato san $n i$ is the recipient (IO), kuruma $o$ is the theme (object), and katteagemashita are action verbs/action. Data (9b) The changes in verb kaimashita be katteagemashita, gives the 
meaning to buy in Indonesian. It shows the emergence of the dative recipient (IO) in the semantic structure of Japanese.

In sentence (10) deletion of the argument (IO) sentence (10a) is not grammatically acceptable in Japanese. This is related to the nature of the verb ageta demanding the presence of (IO) argument in Japanese dative construction and is certainly different from the example sentence (10b). Haha wa argument

\begin{tabular}{|c|c|}
\hline Jiro ga & Hanako ni \\
\hline Jiro-Nom & Hanako-Dat \\
\hline
\end{tabular}

'Jiro will give flowers to Hanako'

$\begin{array}{ll}\text { あげます。 } & \\ \text { hana } o & \text { agemasu. } \\ \text { flower-Ac } & \text { give-FUT }\end{array}$

is the doer (agent), imouto $n i$ is the recipient (IO), okane $o$ is the theme (object), and ageta are action verbs. Data (10a) indicates the disappearance of an indirect object (IO) ungrammatical resulting in the construction. This relates to the use of the verb is a verb ageta who argued three, so it requires the presence of a recipient/benefactive in sentence construction. b.*

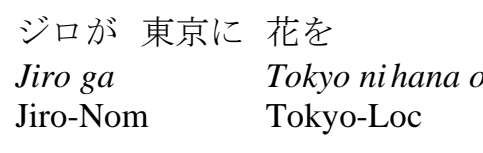

'Jiro will give flowers to Tokyo'
あげます。

agemasu.

flower-Ac give-FUT
In sentence (11) the argument Jiro san wa is an actor (agent), Hanako san $n i$ is the (IO), Hana o is the theme (object), and kaimashita is an action verb/action in sentence (11a). In sentence (11b), the (IO) argument is substituted by Toukyou ni which equally has $\boldsymbol{n i}$ marker. Analysis of sentence (11) shows that the constituent having a dative marker in (11b) is substituted with a noun, then grammatically the Japanese construction is acceptable, but in semantically it becomes unacceptable. In contrast to sentence (11a), it is grammatically and semantically acceptable.

\section{CONCLUSION}

Based on the above analysis, we can make the following conclusions.

1) The verb that requires the presence of an indirect object (OI) is a transitive verb, with $\boldsymbol{n i}$ marker.

2) Verbs analyzed in this study were dative case verbs ageru 'give',

oshieru 'teach', kureru 'give', and kau 'buy'. Semantically these verbs are keizoku doushi 'continuative verbs'. Verbs of this type imply acts at a certain time, and the act or event continued in an utterance. The most obvious characteristic of the verb is always using the infinitive verb $+\sim$ te iru.

The Japanese language has several dative cases, one of them can take an indirect object (IO). It is expected that this research is to distinguish the role of dative cases in more detail.

\section{REFERENCES}

Alwi, Hasan, dkk. 2006. Tata Bahasa Baku Bahasa Indonesia (Ed. III), Jakarta: Balai Pustaka
Aryani, MRD. 2017. "Datif dalam Bahasa Jepang: Kajian Sintaktis dan Semantis". Bandung: Universitas Padjadjaran

Blake, Barry J.2001. Case. Cambridge: Cambridge University Press

Bresnan, J. 2001. Lexical-Functional Syntax. Oxford: Blackwell Publishers.

Butt, Miriam. 2006. Theory of Case. Cambridge: Cambridge University Press

Chafe, W.L. 1970. Meaning and the Structure of Language. Chicago and London:

The University of Chicago Press.

Ekowardono, Karno. 1982. "Konsepsi Morfem Afiks: Sebuah Studi atas Korelasi Bentuk, makna, dan Velensi dalam bahasa Indonesia" in Pelangi Bahasa (ed Harimurti dan Anton Moeliono). Jakarta: Bhratara

Fillmore, Ch. 1968. "The case for case". Dalam: Bach, E. dan R.T. Harms (ed.)

Universal in Linguistic Theory. New York: Holt, Rinehart Winston, 1-88.

Givon. Talmy. 1990. Syntax A Functional Typological Introduction. Vol. II. Amsterdam: John Benjamins Publishing Company.

Givon, Talmy. 2001. Syntax An Introduction. Vol I. Amsterdam: John Benjamins Publishing Company. 
Givon, Talmy. 2001. Syntax An Introduction. Vol II. Amsterdam: John Benjamins Publishing Company.

Hopper, Paul \& Sandra A. Thomson. 1980. Transitivity in Grammar and Discourse. Language 56: 251-299

Katamba, Francis. 1993. Modern Linguistics. Morphology. London: The Macmillan Press

Kuno, Susumu. 1973. Nihon Bunpoo Kenkyuu ; Studi Gramatika Bahasa Jepangee. Tokyo : Taishukan

Nitta, Yoshio. 1991. Nihongo Bunpou Kenkyuu Josetsu. Toukyou-Japan: Kuroshio Shuppan

Sudaryanto. 1983. Predikat-Objek dalam Bahasa Indonesia, Keselarasan Pola Urutan. Jakarta: Djambatan

Sudaryanto. 1993. Metode dan Aneka Teknik Analisis Bahasa. Yogyakarta: Duta Wacana Universitas Press

Sugai, Kazumi. 2000. 'Kakujoshi ni no Imi Tokusetsu ni Kansuru Oboegaki' dalam Hyougo Kyouikudaigaku Kenkyuu Kiyou Vol. 20

Shibatani, Masayoshi. 1976. Syntax and Semantic: The Grammar of Causative Construction. New York: Academi Press

Shibatani, Masayoshi. 1995. Approaches to Language Typology. New York: Oxford University Press
Shibatani, Masayoshi. 2000. Gengo no Kouzou: Rinron to Bunseki. Tokyo: Kuroshio Shuppan

Shibatani, Masayoshi. 2012.Grammatical Relations and Surface Cases. USA: Linguistic Society of America http://www.jstor.org/page/info/about/policies/t erms.jsp

Takahashi, Taro. 2003. Dooshi. Tokyo: Hitsuji Shoten

Tsunoda, Tasaku. 2002. Sekai no Gengo to Nihongo: Gengo Ruikeiron kara Mita Nihongo. Tokyo: Kuroshio Shuppan.

Tsujimura, Natsuko. 1996. An Introduction to Japanese Linguistics. United Kingdom: Blackwell Publishing

Tsujimura, Natsuko. 2004. The Handbook of Japanese Linguistics. London: Blackwell

Verhaar, JWM. 1996. Asas- Asas Linguistik Umum. Yogyakarta: Gadjah Mada University 